\title{
Thoracic Surgical Education: Current and Future Strategies
}

Editor

EDWARD D. VERRIER

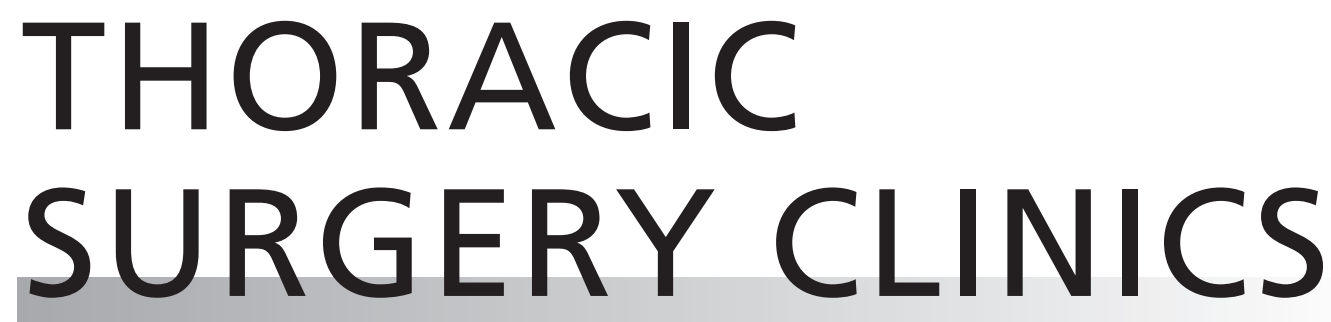

www.thoracic.theclinics.com

Consulting Editor

M. BLAIR MARSHALL

August 2019 • Volume 29 - Number 3 